\title{
GAMBARAN STRATEGI ORANG TUA DALAM PENANGANAN FENOMENA SIBLING RIVALRY PADA ANAK USIA PRA SEKOLAH
}

\author{
Annisa Ayu Marhamah ${ }^{1}$; Fidesrinur ${ }^{1}$ \\ ${ }^{1}$ Program Studi Pendidikan Guru Pendidikan Anak Usia Dini, Fakultas Psikologi dan Pendidikan, \\ Universitas Al-Azhar Indonesia, Jalan Sisingamangaraja, Kebayoran Baru, Jakarta Selatan 12110 \\ Penulis untuk Korespondensi/E-mail: fideza@uai.ac.id
}

\begin{abstract}
Abstrak - Sibling Rivalry merupakan fenomena persaingan yang menimbulkan kecemburuan antara saudara kandung. Dalam penanganannya orang tua harus memiliki pengetahuan mengenai fenomena Sibling Rivalry ini. Penelitian ini bertujuan untuk menggambarkan bagaimana strategi penanganan yang dilakukan orang tua orang pada fenomena Sibling Rivalry pada anak usia pra sekolah 3-6 tahun. Subjek penelitian ini adalah 5 keluarga. Penelitian ini menggunakan metode kualitatif dengan teknik pengumpulan data berupa wawancara, observasi dan dokumentasi. Kemudian data dianalisis dengan tiga tahap yaitu reduksi, display, dan penarikan kesimpulan dengan model Miles dan Huberman. Berdasarkan hasil penelitian dapat diinformasikan bahwa strategi penanganan pada fenomena sibling rivalry pada anak pra sekolah di Kelurahan Cempaka Putih ini, dari ke-5 subjek penelitian hampir sama yakni tidak bersikap pilih kasih, tidak membandingkan anak satu sama lain, dan bersikap adil, serta mengajarkan sikap berbagi antar saudara kandung. Saran dari hasil penelitian ini adalah orang tua perlu meningkatkan pengetahuan-nya mengenai fenomena sibling rivalry pada anak khususnya anak usia pra sekolah dengan pendidikan, media massa/informasi, sosial budaya dan ekonomi, serta lingkungan dan pengalaman, orang tua perlu lebih memperhatikan faktor-faktor penyebab sibling rivalry pada anak, serta orang tua disarankan mencoba berbagai cara dalam strategi pencegahan fenomena sibling rivalry pada anak.
\end{abstract}

Kata Kunci: Pengetahuan Orang Tua, Sibling Rivalry Anak, Anak Pra Sekolah

Abstract - Sibling Rivalry is a competitive phenomenon that causes jealousy between siblings. In handling it, parents must have knowledge about this Sibling Rivalry phenomenon. This study aims to describe how the handling strategies undertaken by parents Sibling Rivalry in pre-school aged children 3-6 years. The subjects of this study were 5 families. This study uses qualitative methods with data collection techniques such as interviews, observation and documentation. Then the data were analyzed in three stages, namely reduction, display, and drawing conclusions with the Miles and Huberman models. Based on the results of the study can be informed that the strategy of handling the sibling rivalry phenomenon in pre-school children in the Cempaka Putih Village, of the 5 research subjects is almost the same that is not being favoritism, not comparing children with each other, and being fair, and teaching attitudes sharing between siblings. Suggestions from the results of this study are parents need to increase their knowledge about the phenomenon of sibling rivalry in children, especially pre-school age children with education, mass media / information, socio-cultural and economic, as well as the environment and experience, parents need to pay more attention to factors the cause of sibling rivalry in children, and parents are advised to try various ways in the prevention of sibling rivalry phenomenon in children.

Keyword: Parents' Knowledge, Sibling Rivalry Children, Pre-School Children 


\section{PENDAHULUAN}

$\mathrm{A}$ nak merupakan dambaan setiap keluarga. Memiliki anak berarti memiliki keturunan yang akan menjadi penerus sebuah keluarga. Masa kanak-kanak merupakan masa yang istimewa, yang disebut juga sebagai masa Golden Age. Golden Age merupakan masa keemasan dimana pada masa ini disebut-sebut sebagai masa penentu bagi kehidupan anak selanjutnya. Masa kanak-kanak ini disebut dengan masa kanak-kanak awal. Masa kanak-kanak awal (early childhood) merupakan periode perkembangan yang terjadi mulai akhir masa bayi (18-24 bulan) hingga sekitar usia 5-6 tahun, kadang periode ini disebut tahun-tahun pra sekolah. Selama waktu tersebut, anak kecil belajar menjadi mandiri dan merawat diri sendiri, mereka mengembangkan keterampilan kesiapan sekolah (mengikuti perintah, mengenali huruf), dan mereka mengahabiskan berjam-jam untuk bermain dengan teman sebaya (Santrock dalam Sufiani 2013).

Batasan karakteristik anak usia pra sekolah adalah antara 3 (tiga) sampai dengan 6 (enam) tahun (Hidayat, dalam Saurlina 2015). Pada tahap perkembangan anak usia pra sekolah ini, anak mulai menguasai berbagai keterampilan fisik, bahasa, dan anak pun mulai memiliki rasa percaya diri untuk mengeksplorasi kemandiriannya (Hurlock dalam Rawania 2014).

Menurut Wong (dalam Fibrila, 2016) Periode pra sekolah dari usia 3-6 tahun ini dimulai dari waktu anak bergerak sambil berdiri sampai mereka masuk sekolah, dicirikan dengan aktivitas yang tinggi. Perkembangan anak pra sekolah tersebut mencangkup beberapa aspek yaitu motorik kasar, motorik halus, bahasa dan sosial. Untuk mencapai perkembangan tersebut dibutuhkan peran orang lain untuk membantu. Pada umumnya ibu merupakan pemegang peran utama bagi anak-anaknya. Sejak masa kehamilan, melahirkan, menyusui hingga memelihara anak-anaknya. Seorang ibu juga berperan dalam hal pendidikan untuk anggota keluarganya. Pendidikan yang dimaksud adalah apa yang diajarkan oleh ibu kepada anaknya. Ini membuat ibu disebut-sebut adalah sosok yang paling dekat dengan anak.
Perkembangan anak tergantung kepada pola asuh seorang ibu, jika pola asuhnya baik akan berbanding lurus dengan perkembangan anak nantinya. Maka sangatlah penting pengetahuan ibu untuk mengasuh anaknya secara baik dan benar untuk proses tumbuh kembang anak. Seorang ibu diharapkan dapat menstimulasi anak dengan bermain dan berinteraksi dengan lingkungannya, berolahraga dan beraktivitas kreatif lainnya agar stimulasi untuk perkembangan otak anak semakin lengkap (Kuwat M. dalam Soetjiningsih, 2012).

Dilihat dari budaya, pengasuhan anak saat ini hanya dilakukan oleh seorang ibu. Tugas para ayah semata hanya untuk bekerja mencari nafkah. Padahal peran ayah juga memberi banyak pengaruh pada anak. Menurut Rosenberg, Jeffrey \& Wilcox (dalam Astuti, 2015) Ayah yang terlibat aktif dalam pengasuhan anak di masa kecilnya akan mendorong anak lebih berprestasi secara akademis di masa dewasanya. Dalam pengasuhan tersebut dibutuhkan pemahaman khusus atau pengetahuan mengenai pengasuhan anak demi tercapainya perkembangan anak di masa depan.

Oleh karena itu orang tua diharuskan memiliki pengetahuan. Pengetahuan ini sangatlah penting bukan hanya bagi perkembangan tumbuh kembang anak, melainkan juga bagi mental dan sosio emosional anak. Bagi orang tua yang baru memiliki anak satu mungkin mudah karena memberi perhatian hanya kepada satu anak saja. Pada jaman sekarang, anak satu belum lah cukup untuk memuaskan keinginan para orang tua untuk memiliki anak. Maka banyak orang tua memuntuskan untuk memiliki anak lagi. Namun ketika hadir anak kedua inilah orang tua mulai kesulitan karena fokusnya terbagi untuk dua anak. Satu sisi orang tua tidak bisa mengabaikan anak pertama, namun sisi lainnya orang tua juga harus memenuhi kebutuhan anak kedua yang terlihat membutuhkan lebih banyak perhatian.

Masalah lain muncul ketika anak pertama merasa cemburu karena terabaikan oleh ayah dan ibunya yang mulai sibuk dengan keadaan anak kedua sehingga anak pertama merasa tidak mendapat perhatian yang sama seperti dulu lagi. Hal ini dikarenakan kehadiran anggota baru dalam keluarga mengakibatkan anak mulai beradaptasi dengan perubahan baru yang terjadi 
(Potter \& Perry dalam Nurhidayah, dkk. 2018). Anderson (dalam Raisya, 2016) menambahkan proses adaptasi yang tidak disiapkan dengan baik ini dapat memicu rasa cemburu anak pada adik kandungnya. Meskipun dalam menanganinya, beberapa anggota keluarga yang lain seperti nenek, kakek, paman ataupun bibi membantu dalam menjaga dan mengajak anak pertama bermain, namun tidak dapat dipungkiri sang anak masih tetap merasa cemburu akan kehadiran anak kedua. Perasaan cemburu yang dimiliki anak ini dapat menimbulkan perubahan sikap pada sang anak. Seiring bertambahnya usia anak pertama yang mulai semakin aktif, sikap dan perilaku anak pertama ini perlahan mulai berubah. Bisa tiba-tiba sang anak marah tanpa sebab, mulai lebih sering menangis, bahkan berkata kasar hanya demi mendapat perhatian ayah dan ibu. Masalah seperti inilah yang menimbulkan fenomena yang disebut sibling rivalry.

Sibling rivalry menurut Shaffer (dalam Jatmiko, 2015) adalah suatu kompetisi, kecemburuan dan kebencian antara saudara kandung, yang sering muncul saat hadirnya saudara yang lebih muda. Menurut Putri dan Hendriyani (2013) sibling rivalry terjadi karena seseorang merasa takut kehilangan kasih sayang dan perhatian dari orang tua, sehingga menimbulkan berbagai pertentangan dan akibatnya dapat membahayakan bagi penyesuaian pribadi dan sosial seseorang.

Sibling rivalry seringkali menimbulkan dampak pada anak pertama maupun anak kedua. Menurut Havnes (dalam Rahmawati, 2013), sibling rivalry menimbulkan dampak negatif dan positif terhadap perkembangan anak. Dampak positif dari sibling rivalry ini yaitu saat saudara lahir, anak yang lebih tua telah mengembangkan kemandirian penuh, terutama dalam bermain, dan peningkatan kemampuan untuk bertanggung jawab yang mengarah ke konsep diri yang lebih bagus. Dampak yang negatifnya yaitu mencederai saudaranya seperti akan memukul, mendorong, dan mencakar lawannya, sedangkan pada anak yang lebih besar cenderung akan memaki saudara atau menganggap saudara sebagai lawan. Menurut Priatna dan Yulia (dalam Nurmira, 2017) Dampak yang paling fatal dari sibling rivalry ini adalah putusnya tali persaudaraan jika kelak orang tua meninggal. Pertengkaran yang terus menerus dipupuk sejak kecil ini akan terus meruncing saat anak-anak beranjak dewasa.

Menurut penelitian yang dilakukan oleh Putri (2013), sibling rivalry yang terjadi pada anak usia dini membawa beberapa perubahan atau dampak yaitu dampak pada diri sendiri, yakni agresi, termper tantrum, emosi yang meledak ledak, gangguan kepercayaan diri dan perasaan dendam pada saudara kandung. Dampak yang kedua adalah dampak terhadap saudara kandung yaitu agresi, tidak mau berbagi dengan saudara, tidak mau membantu saudara, mengadukan saudara, dominasi pada saudara dan model negatif pada saudara.

Dampak dari sibling rivalry pada anak usia inilah yang dapat membahayakan hubungan persaudaraan kakak adik di masa depan kelak. Dampak negatif tersebut dapat dihindari dan merubahnya menjadi dampak positif ketika orang tua bisa mengatasi dengan sikap dan pengetahuan. Pengetahuan yang dibutuhkan tentunya ialah pengetahuan tentang pencegahan fenomena dari masalah sibling rivalry pada anak tersebut. Pencegahan tersebut sangat perlu dilakukan sejak dini. Maka dari itu sangatlah penting bagi orang tua memiliki pengetahuan tentang sibling rivalry ini.

Namun menurut hasil penelitian yang dilakukan Wandari dengan judul Pengetahuan Orang Tua tentang Sibling Rivalry Pada Anak Usia Pra Sekolah dengan populasi sebanyak 58 orang tua dan jumlah responden sebanyak 49 orang di TK A-Huda Branti Raya II menggambarkan sebanyak 22 orang $(44,9 \%)$ berpengetahuan kurang baik, 15 orang $(30,6 \%)$ cukup baik, dan 12 orang $(24,5 \%)$ baik. Hasil tersebut tentu sangat memprihatinkan dimana hasilnya didominasi dengan orang tua yang berpengetahuan kurang baik (Wandari, 2015)

Sehubung dengan permasalahan dan penelitian terdahulu di atas, peneliti menutuskan untuk melakukan penelitian fenomena ini, dimana peneliti memfokuskan penelitian ini pada bagaimana strategi penanganan pada fenomena sibling rivalry anak usia pra sekolah di Kelurahan Cempaka Putih.

\section{METODE PENELITIAN}

Metode penelitian yang digunakan adalah kualitatif. Bogdan dan Taylor (Moleong, 2012) 
mendefinisikan metodologi kualitatif sebagai prosedur penelitian yang mengasilkan data deskriptif berupa kata-kata tertulis atau lisan dari orang-orang dan perilaku yang dapat diamati. Subjek penelitian ini adalah 5 (lima) orang tua di RW 05 Kelurahan Cempaka Putih, Ciputat Timur dengan ketentuan yakni orang tua yang memiliki 2 (dua) anak atau lebih yang memiliki anggota keluarga selain keluarga inti seperti paman, bibi, nenek atau kakek. Subjek penelitian juga diambil dari keluarga yang bersedia untuk dilakukan penelitian dan keluarga yang memiliki waktu luang yang cukup. Peneliti Sumber data yang digunakan adalah data primer dan sekunder. Sumber data yang dimaksud pada penelitian ini adalah sumber data dimana peneliti mendapatkan data (Arikunto dalam Erliana 2013).

Teknik pengumpulan data dalam metode kualitatif yang terpenting untuk digunakan adalah: wawancara, observasi dan dokumentasi. Menurut Sugiyono (2013) teknik pengumpulan data merupakan langkah yang paling strategis dalam penelitian, karena tujuan utama dari penelitian adalah mendapatkan data. Instrumen yang digunakan dalam penelitian adalah pedoman observasi dan pedoman wawancara. Analisis data menggunakan analisis Miles dan huberman dalam Sugiyono (2011), yakni aktivitas analisis data kualitatif dilakukan secara interaktif dan berlansung secara terus menerus sampai tuntas. Aktivitas dalam analisis data ini yaitu reduction, data display, dan verification.

\section{HASIL DAN PEMBAHASAN}

Penelitian ini mengambil subjek penelitian 5 (lima) keluarga yang memiliki 2 (dua) anak atau lebih yang berusia 3-6 tahun dari Kelurahan Cempaka Putih. Adapun keluarga tersebut sengaja ditulis dengan inisial $\mathrm{S} 1$ (Subjek Penelitian 1), S2 (Subjek Penelitian 2), S3 (Subjek Penelitian 3), S4 (Subjek Penelitian 4) dan S5 (Subjek Penelitian 5).

\section{Subjek penelitian 1}

Subjek dari keluarga pertama (S1) yaitu ayah RS. RS Merupakan ayah dari 3 orang anak yakni anak pertama yang berusia 12 tahunyang berjenis kelamin perempuan yang bernama AHS, anak kedua yang berusia 6 tahun yang berjenis kelamin perempuan yang bernama SS dan anak terakhir IHS yang berusia 3 tahun berjenis kelamin laki-laki, serta ibunya bernama PW. Sang ayah berprofesi sebagai Direktur yang memiliki latar belakang pendidikan S1 Psikologi. Sedangkan sang ibu, PW adalah Guru TPA dan memiliki latar belakang pendidikan yakni S1 Tarbiyyah.

Orang tua dari keluarga subjek penelitian 1 mengungkapkan mereka menangani fenomena Sibling Rivalry pada anak-anaknya. Orang tua selalu menjelaskan kepada anak-anaknya jika misalnya salah satu saudara kandungnya tengah butuh banyak perhatian seperti sedang sakit, orang tua memberi pengertian bahwa orang tua harus mengurusi saudaranya terlebih dahulu. Orang tua juga mengaku tidak bersikap pilih kasih dan bersikap adil pada semua anak. Orang tua juga mengajarkan sikap berbagi kepada anak-anaknya dengan cara berbagi dalam hal makanan. Sang ibu PW yang bertugas mengatur keuangan keluarga juga mengajarkan anakanaknya untuk berbagi uang jajan. Anak tertua diberikan uang yang kemudian diberikan juga kepada adik-adiknya.

\section{Subjek penelitian 2}

Subjek dari keluarga kedua (S2) yaitu ayah AB. AB Merupakan ayah dari 2 orang anak laki-laki yakni MKB yang berusia 6 tahun 4 bulan dan MAB yang berusia 3 tahun 6 bulan, serta ibunya bernama SF. Sang ayah berusia 31 tahun, berprofesi sebagai karyawan di perusahaan swasta yang memiliki latar belakang pendidikan Sekolah Menengah Atas (SMK). Sedangkan sang ibu berusia 27 tahun, SF adalah ibu rumah tangga yang berlatar belakang pendidikan Sekolah Menengah Kejuruan (SMK).

Orang tua dari keluarga subjek penelitian 2 diketahui orang tua belum menerapkan pengetahuannya mengenai sibling rivalry dikarenakan ketidaktahuannya tentang bagaimana menerapkan hal tersebut pada anakanaknya. Namun orang tua dalam kehidupannya selalu mengajarkan sikap saling berbagi kepada anak-anaknya. Sang ibu SF mengaku terkadang ia membelikan jajanan untuk anak-anaknya berbeda satu sama lain dari situ ia mengajarkan jika salah satu saudaranya menginginkan jajanan yang ia punya, ia harus berbagi. Begitupun sebaliknya dilakukan. Orang tua juga tidak bersikap pilih kasih, tidak pernah 
membandingkan anak satu sama lain dan bersikap adil.

\section{Subjek penelitian 3}

Subjek dari keluarga ketiga (S3) yaitu keluarga ayah AS. AS merupakan ayah dari 4 orang anak yakni GG anak pertama yang berusia 11 tahun berjenis kelamin laki-laki, GH anak kedua yang berusia 8 tahun berjenis kelamin laki-laki, ZGS anak ketiga yang berusia 5 tahun yang juga berjenis kelamin laki-laki dan KKG anak terakhir yang berusia 3 tahun berjenis kelamin perempuan. Ibu dari keluarga S3 bernama WN. Sang ayah bekerja sebagai karyawan mebel dengan latar belakang pendidikan Sekolah Menengah Atas (SMA). Sedangkan sang ibu WN bekerja sebagai pembantu rumah tangga yang jaraknya berdekatan dengan rumahnya. Sang ibu memiliki latar belakang pendidikan yang sama dengan sang ayah yakni Sekolah Menengah Atas (SMA).

Orang tua dari subjek penelitian 3 mengaku tidak menerapkan pengetahuan mengenai sibling rivalry yang dimilikinya kepada anakanaknya. Namun orang tua dari subjek penelitian 3 mengaku mengajarkan anakanaknya sikap berbagi dengan cara seperti tidak pelit untuk berbagi makanan ke sesama saudaranya. Orang tua juga tidak bersikap pilih kasih, tidak pernah membandingkan anak satu sama lain dan bersikap adil. Orang tua juga menambahkan perannya sebagai orang tua ialah mengajari dan mengurusi kebutuhan anak.

\section{Subjek penelitian 4}

Subjek dari keluarga keempat (S4) yaitu keluarga ayah JW. Ayah JW merupakan ayah dari 2 orang anak laki-laki yakni JYT yang berusia 4 tahun 8 bulan dan ZYA yang berusia 3 tahun serta sang istri atau ibu bernama NS. Ayah JW berusia 29 tahun, berprofesi sebagai koki di sebuah restoran dengan latar belakang pendidikan Sekolah Menengah Atas (SMK). Sedangkan sang ibu NS merupakan ibu rumah tangga berusia 23 tahun yang memiliki latar belakang pendidikan yang juga Sekolah Menengah Atas (SMA).

Orang tua dari subjek penelitian 4, mereka mengaku tidak menerapkan pengetahuan mengenai sibling rivalry pada anak-anak mereka. Mereka juga baru mengetahui informasi mengenai sibling rivalry ini dari penjelasan peneliti. Mereka menyadari bahwa untuk mencegah terjadinya Sibling Rivalry ini orang tua perlu memperkirakan jarak kelahiran antara anak satu dengan anak yang lainnya. Meski demikian orang tua mengaku untuk menghindari hal tersebut, orang tua selalu bersikap adil dan mengajarkan sikap berbagi pada anak. Misalnya dengan berbagi mainan untuk dimainkan bersama.

\section{Subjek penelitian 5}

Subjek dari keluarga terakhir (S5) adalah keluarga ayah FD. FD merupakan ayah dari 4 orang anak yakni anak pertama yang bernama YS berusia 11 tahun yang berjenis kelamin perempuan, anak kedua bernama IH yang berusia 7 tahun berjenis kelamin laki-laki, anak ketiga yang bernama AY yang berusia 6 tahun berjenis kelamin perempuan, anak terakhir yang bernama ST yang berusia 3 tahun yang berjenis kelamin perempuan dan sang ibu yang bernama DN. Ayah FD berusia 36 tahun dan berprofesi sebagai pegawai koperasi bank swasta yang berlatar belakang pendidikan Sekolah Menengah Pertama. Sedangkan sang ibu DN berusia 2 tahun diatas sang ayah yakni 38 tahun yang merupakan ibu rumah tangga yang memiliki latar belakang pendidikan Sekolah Menengah Kejuruan (SMK).

Orang tua dari subjek penelitian 5 diketahui orang tua menerapkan pengetahuannya mengenai fenomena sibling rivalry ini pada anak. Sang ibu selalu menjelaskan kepada anakanaknya bahwa antar sesama saudara kandung tidak boleh ada persaingan yang menyebabkan kecemburuan karena pada setiap anak pasti ada masanya masing-masing. Orang tua juga tidak bersikap pilih kasih, tidak membandingkan anak satu sama lain dan bersikap adil pada semua anak. Orang tua juga menambahkan perannya sebagai orang tua ialah seperti role model anak.

Strategi dalam penanganan fenomena sibling rivalry pada kelima anak subjek penelitian hampir sama yakni tidak bersikap pilih kasih, tidak membandingkan anak satu sama lain, dan bersikap adil. Orang tua juga mengajarkan sikap berbagi antar saudara kandung. Bahkan orang tua subjek penelitian 1 dan 5 menjelaskan kepada anak-anaknya mengenai fenomena ini. Strategi tersebut tertulis dalam beberapa hal yang perlu diperhatikan orang tua untuk 
mengatasi sibling rivalry menurut Marmi (2012) yakni tidak membandingkan antara anak satu sama lain, membuat anak-anak mampu bekerja sama daripada bersaing satu sama lain seperti mengajarkan sikap berbagi serta bersikap adil yang disesuaikan dengan kebutuhan anak. Sehingga adil bagi anak satu dengan yang lain berbeda.

Selain strategi tersebut orang tua memiliki peran dalam keluarga. Orang tua dari subjek penelitian 1 mengatakan mereka merupakan contoh teladan bagi anak-anaknya. Mereka juga terlibat langsung dalam pendidikan anak mereka. Orang tua dari subjek penelitian 2 menjelaskan perannya sebagai orang tua adalah mengurus semua kebutuhan anak. Orang tua dari subjek penelitian 3 menjelaskan perannya sebagai orang tua yakni mengajari dan mengurusi kebutuhan anak-anak mereka. Orang tua dari subjek penelitan 4 menjelaskan perannya seperti orang tua dari subjek penelitian 2 yakni mengurus semua kebutuhan anak. Sedangkan orang tua dari subjek penelitian 5 menjelaskan orang tua sebagai role model anak. Jika ingin anak baik maka orang tua harus memberi contoh yang baik.

Peran tersebut sejalan dengan prinsip peran keluarga atau orang tua menurut Covey (Yusuf, 2009) yakni orang tua sebagai Modelling atau contoh teladan bagi seorang baik menjalankan nilai-nilai spiritual atau agama dan norma yang berlaku di masyarakat. Orang tua sebagai Organizing yaitu mengatur, mengontrol, merencanakan, bekerja sama dalam menyelesaikan setiap permasalahan yang terjadi, meluruskan struktur dan sistem keluarga dalam rangka membantu menyelesaikan hal-hal yang penting serta memenuhi semua kebutuhan keluarga. Serta orang tua sebagai Teaching yakni orang tua adalah guru yang mempunyai tanggung jawab mendorong, mengawasi, membimbing, mengajarkan anak-anaknya tentang nilai spiritual, moral, sosial serta mengajarkan prinsip-prinsip kehidupan sehingga anak memahami dan melaksanakannya.

\section{SIMPULAN DAN SARAN}

Berdasarkan pembahasan di atas dapat disimpulkan bahwa masing-masing orang tua memiliki strategi penanganan pada fenomena sibling rivalry ini. Strategi penanganan pada fenomena sibling rivalry pada anak pada 5 subjek penelitian hampir sama yakni tidak bersikap pilih kasih, tidak membandingkan anak satu sama lain, dan bersikap adil, serta juga mengajarkan sikap berbagi antar saudara kandung. Begitu pula bagaimana masingmasing peran orang tua dalam kehidupan anak.

Saran dari hasil penelitian ini adalah orang tua perlu meningkatkan pengetahuan-nya mengenai fenomena sibling rivalry pada anak khususnya anak usia pra sekolah dengan pendidikan, media massa/ informasi, sosial budaya dan ekonomi, serta lingkungan dan pengalaman, orang tua perlu lebih memperhatikan faktorfaktor penyebab sibling rivalry pada anak, serta orang tua disarankan mencoba berbagai cara dalam strategi pencegahan fenomena sibling rivalry pada anak.

\section{DAFTAR PUSTAKA}

Astuti, V. (2015). Pengalaman Keterlibatan Ayah dalam Pengasuhan Anak (Studi Kualitatif Fenomenologis). Fakultas Psikologi Universitas Diponegoro. ejournal3.undip.ac.id. Diakses pada 8 Januari 2020.

Ambarwati, E.R., dan Wulandari, D. (2008). Asuhan Kebidanan Nifas. Yogyakarta: Mitra Cendikia Press.

Dewi, V.N.L., Sunarsih, T. (2011). Asuhan Kebidanan Pada Ibu Nifas. Jakarta: Salemba Medika.

Erliana, Y.W. (2013). Efektivitas Managemen Preventative dalam Mengatasi Perilaku Disruptif Siswa Pada Pembelajaran PAI di SMA Antartika Sidoarjo. UIN Sunan Ampel Surabaya. Naskah Publikasi. Digilib.uninsby.ac.id. Diakses pada 8 Januari 2020.

Fibrila, F. (2016). Kualitas Pertumbuhan Pada Masa Bayi Terhadap Pencapaian Perkembangan Pada Anak Pra Sekolah. Program Studi Kebidanan Metro Politeknik Kesehatan Tajung Karang. ejurnal.poltekkes-tjk.ac.id. Diakses pada 8 Januari 2020.

Jatmiko, A.A. (2015). Determinan Perilaku Sibling Rivalry Pada Anak Yang Memiliki Saudara Kandung di Raudhatul Athfal Miftahul Huda Desa Selandaka Kecamatan Sumpiuh Kabupaten Banyumas. Universitas Muhammadiyah 
repostitory.ump.ac.id. Diakses pada 8 Januari 2020.

Lamb, M. E. (1997). The role father in child development $\left(3^{\text {rd }}\right.$ ed.). New York: Wiley.

Marmi. (2012). Asuhan kebidanan pada masa nifas. Yogyakarta: Pustaka Pelajar.

Santrock, J.W. (2007). Perkembangan anak. Jilid 1 Edisi Kesebelas. Jakarta: PT. Erlangga.

Moleong, L. J. (2012). Metodologi penelitian kualitatif. Bandung: PT Remaja Rosdakarya.

Notoatmodjo, S. (2012). Promosi kesehatan dan perilaku kesehatan. Edisi 1. Jakarta: Rineka Cipta.

Nurhidayah, I. ,dkk. (2018). hubungan sibling rivalry dengan cedera pada anak usia balita di desa cipacing kecamatan jatinagor. fakultas keperawatan universitas padjajaran. Journal.stikep.ppnijabar.ac.id. Diakses pada 8 Januari 2020.

Nurmira. (2017). hubungan pengasuhan orang tua terhadap anak dengan kejadian perilaku sibling rivalry pada anak usia dini (1-5 tahun) di paud genus kid's di puhun pintu kabun bukittinggi. Program Studi Ilmu Keperawatan Sekolah Tinggi Ilmu Kesehatan. Padang. Repo.stikesperintis.ac.id. Diakses pada 8 Januari 2020.

Pangaribuan, S. (2015). Hubungan lama penggunaan gatget dengan tumbuh kembang anak usia prasekolah di tk nomensen di bontang tahun 2014. Program Studi Ilmu Keperawatan Sekolah Tinggi Ilmu Kesehatan Muhammadiyah. Samarinda. Dspace.umkt.ac.id. Diakses pada 8 Januari 2020.

Putri, PA.C.T., Deliana, S.M., dan Hendriyani, R. (2013). Dampak Sibling Rivalry (Persaingan Saudara Kandung) Pada Anak Usia Dini. Jurnal Development and Clinical Psychologi.
Rahmawati, A. (2013). Sibling rivalry pada anak usia dini. Jurnal Ilmiah Pendidikan, Sejarah dan Sosial Budaya, Vol. 15, No.1.

Rawania. (2014). Meningkatkan interaksi sosial melalui metode bermain peran di kelompok B2 TK Madani Palu. Naskah Publikasi. Universitas Tadulako.

Sawitri. (2009). Sibling rivalry. http://www.kompaseybermedia.com. 23 Oktober 2013.

Soetjiningsih, H.C. (2012). Tumbuh kembang dan psikologi anak usia preschool. Jakarta: Rineka Cipta.

Sufiani. (2013). Perancangan buku ilustrasi pengenalan manfaat buah untuk anak usia 6-9 tahun. Naskah Publikasi. Universitas Multi Media Nusantara.

Sugiyono. (2011). Metode penelitian kuantitatif kualitatif dan $R \& D$. Bandung: Alfabeta.

Wandari, N. (2015). Pengetahuan orang tua tentang sibling rivalry pada anak usia pra sekolah. Keperawatan Poltekkes Tanjungkarang. Ejurnal.poltekkes-tjk.ac.id. Diakses pada 26 Agustus 2019.

Wijaya, R.T. (2016). Gambaran pengetahuan ibu mengenai sibling rivalry pada anak usia toddler di Kelurahan Cikutra Kecamatan Cibeunyil Kidul. Program Studi DIII Keperawatan. Fakultas Pendidikan Olahraga dan Kesehatan. Universitas Pendidikan Indonesia. Repository.upi.edu. Diakses pada 8 Januari 2020.

Yusuf, S. (2009). Psikologi perkembangan anak dan remaja. Bandung: PT Remaja Rosdakarya. 